\title{
Stable Isotopes of Water and Nitrate for the Identification of Groundwater Flowpaths: A Review
}

\author{
Hyejung Jung ${ }^{1}{ }^{1}$, Dong-Chan Koh ${ }^{2}{ }^{\oplus}$, Yun S. Kim ${ }^{3}$, Sung-Wook Jeen ${ }^{4} \mathbb{D}^{\mathbb{D}}$ and \\ Jeonghoon Lee ${ }^{1, * \mathbb{D}}$ \\ 1 Department of Science Education, Ewha Womans University, Seoul 03760, Korea; \\ hyejeong.chung@gmail.com \\ 2 Groundwater Department, Geologic Environment Division, Korea Institute of Geoscience and Mineral \\ Resources, Daejeon 34132, Korea; chankoh@kigam.re.kr \\ 3 Water Quality Research Center, K-Water Convergence Institute, Daejeon 34350, Korea; yunskim@kwater.or.kr \\ 4 Department of Earth and Environmental Sciences \& The Earth and Environmental Science System Research \\ Center, Jeonbuk National University, Jeonju 54896, Korea; sjeen@jbnu.ac.kr \\ * Correspondence: jeonghoon.lee@ewha.ac.kr; Tel.: +82-2-3277-3794
}

Received: 1 December 2019; Accepted: 30 December 2019; Published: 1 January 2020

\begin{abstract}
Nitrate contamination in stream water and groundwater is a serious environmental problem that arises in areas of high agricultural activities or high population density. It is therefore important to identify the source and flowpath of nitrate in water bodies. In recent decades, the dual isotope analysis $\left(\delta^{15} \mathrm{~N}\right.$ and $\left.\delta^{18} \mathrm{O}\right)$ of nitrate has been widely applied to track contamination sources by taking advantage of the difference in nitrogen and oxygen isotope ratios for different sources. However, transformation processes of nitrogen compounds can change the isotopic composition of nitrate due to the various redox processes in the environment, which often makes it difficult to identify contaminant sources. To compensate for this, the stable water isotope of the $\mathrm{H}_{2} \mathrm{O}$ itself can be used to interpret the complex hydrological and hydrochemical processes for the movement of nitrate contaminants. Therefore, the present study aims at understanding the fundamental background of stable water and nitrate isotope analysis, including isotope fractionation, analytical methods such as nitrate concentration from samples, instrumentation, and the typical ranges of $\delta^{15} \mathrm{~N}$ and $\delta^{18} \mathrm{O}$ from various nitrate sources. In addition, we discuss hydrograph separation using the oxygen and hydrogen isotopes of water in combination with the nitrogen and oxygen isotopes of nitrate to understand the relative contributions of precipitation and groundwater to stream water. This study will assist in understanding the groundwater flowpaths as well as tracking the sources of nitrate contamination using the stable isotope analysis in combination with nitrate and water.
\end{abstract}

Keywords: groundwater; isotope hydrology; stable water isotopes; stable nitrate isotopes

\section{Introduction}

Identifying groundwater flowpaths can provide important information regarding the movements of water itself and of contaminants therein via interaction with surface water. For example, contaminants can be discharged directly into the stream water but, if they are recharged into groundwater that then passes indirectly into stream water, the groundwater can contribute significantly to the water quality of the stream [1]. In particular, since nitrate is highly mobile and primarily originates from nonpoint source pollution, it is distributed across a wide area through various groundwater flowpaths and it can be difficult to trace the source [2]. In order to effectively control the spread of contaminants, and to clean up the contaminated stream water, it is therefore important to understand the flowpath of groundwater [3]. 
While concentration-based chemical analyses such as total nitrogen (TN), total phosphorus (TP), total organic carbon (TOC), biochemical oxygen demand (BOD), and chemical oxygen demand (COD) have traditionally been used to effectively trace mixed contamination, this approach does not easily track contaminant movement and physical processes [4]. By contrast, stable isotope analysis is an effective tool for identifying sources, inferring processes, and determining the contributions of various inputs [5]. In particular, stable water isotopes $\left(\delta^{18} \mathrm{O}\right.$ and $\left.\delta \mathrm{D}\right)$ are affected by meteorological processes that provide a characteristic fingerprint of their origin, which is essential for investigating the source of groundwater [6]. The stable isotopes of nitrogen and oxygen in nitrate $\left(\delta^{15} \mathrm{~N}\right.$ and $\left.\delta^{18} \mathrm{O}\right)$ are also fundamental to identifying the sources of nitrate contamination because the isotopic values are distinct from source to source [7].

While the stable water isotopes have been used as tracers in hydrograph separation studies since the pioneering work of Craig [8], the stable nitrate isotopes have been used to identify nitrate sources since nitrate contaminants became an environmental issue in the 1970s. Even now, nitrate is a very common groundwater pollutant, imposing a serious threat to drinking water supplies and contributing to eutrophication of surface waters [9-11]. Nitrate is the dominant nitrogen species in groundwater, which may be derived from soil organic nitrogen, synthetic fertilizer, livestock waste, sewage effluent, and atmospheric precipitation [11]. In some areas, atmospheric deposition of anthropogenic nitrogen exceeds ecosystem nutrient demand and the influence of atmospheric deposition on nitrogen export has not been well-documented for short-term discharge events such as rainfall and snowmelt [12].

Isotopic hydrograph separation using stable isotopes in water and nitrate provides a useful tool for determining the water flowpath and the source of nitrates. This approach has been widely used to understand the proportion of different water sources contributing to stream water, which can be used to infer the flowpath and residence time [13-16]. In particular, distinguishing between nitrate sources such as direct atmospheric deposition or biological assimilation and release in the soil zone may reveal the flowpath of groundwater into stream or river water [12]. Hence, the isotopic analysis of nitrogen and oxygen in nitrates (the dual isotopic technique) has been used to identify the source of nitrate in many studies. For example, Böttcher et al. [17] determined the sources of nitrate in groundwater downgradient from an agricultural area and Durka et al. [18] later determined the sources of nitrate in an undisturbed watershed in Bavaria, Germany. The dual isotope approach can be used to determine the source of nitrate in stream water because of the distinct isotopic signature of nitrate sources such as event water (rainfall or snowmelt), soil water, and groundwater.

To study the hydrograph separation of stable water isotopes, it is important to understand how precipitation infiltrates into soil water or recharges into groundwater and is subsequently released into stream water. To this end, studies on stable water isotopes in the atmospheric source must first be conducted in order to form a basis for understanding and predicting the movement of contaminants in the groundwater flowpath [16]. For the past 40 years, many studies have been conducted using the hydrograph separation technique through stable water isotopes or conservative chemical tracers to investigate the movement of water components such as groundwater, rainfall, snowmelt, and soil water in the stream water [16,19-26]. In particular, Ladouche et al. [20] investigated the streamflow components using hydrograph separation with stable water isotopes, major chemical parameters, and dissolved organic carbon (DOC). Dahlke et al. [22] used the value of the stable oxygen isotope $\left(\delta^{18} \mathrm{O}\right)$ of water to indicate that the majority of storm runoff was dominated by pre-event water in the $30 \%$ glaciated sub-arctic catchment of Tarfala, northern Sweden. Later, Rahman et al. [24] conducted an end-member mixing analysis to describe the daily variation of runoff components in the Alpine watershed, and Kim et al. [16] used chemical and isotopic tracers to identify the impact of the pre-event water component of a granitic watershed with a thin soil layer.

Isotope hydrology involves measuring the stable isotopic compositions of precipitation, stream water, and groundwater samples, then interpreting these measurements in order to quantify or conceptualize the groundwater flowpath and velocity profile along with hydrogeochemical and biogeochemical reactions. With more conventional hydrogeological and hydrogeochemical data, 
such as information on lithology, meteorology, and solute concentrations, isotopic approaches have been helpful in identifying water movement among various reservoirs, e.g., evapotranspiration, groundwater recharge, discharge, and runoff [12,15,27-31]. The present paper is focused on isotope hydrology reviews dealing with methodological advances and their limitations and lessons drawn from decades of research. This review is motivated by the importance of understanding the groundwater flowpath to rivers and/or streams via analysis of isotopes in water and nitrates. After briefly introducing the systematic processes affecting the oxygen and hydrogen isotopes from precipitation to groundwater and the nitrogen and oxygen isotopes of nitrates, the review goes on to examine the commonly applied isotopic technique of hydrograph separation using stable water isotopes. Hence, this study will help to understand the groundwater flowpath and the tracking of nitrate contamination to its source using the stable isotope analysis of nitrate and water.

\section{Hydrograph Separation}

Hydrograph separation is the separation of streamflow components into two or more different components that contribute to the stream in a small catchment area or watershed. For example, isotopic hydrograph separation using isotopic tracers was first proposed by Dincer et al. [32], was developed by Sklash and Farvolden [19], and has been evaluated in many studies [33]. The isotopic hydrograph separation technique is based on the assumption that two components contribute to the stream after the precipitation occurs, namely: (1) The runoff caused by the rainwater (new water) and (2) the groundwater (old water). To separate the stream water discharge into rainwater and groundwater components, a two-component mixing model was used. The following mass balance equations introduced by Sklash and Farvolden [19] can be used:

$$
\begin{gathered}
Q_{t}=Q_{r}+Q_{g} \\
C_{t} Q_{t}=C_{r} Q_{r}+C_{g} Q_{g} \\
x=\frac{C_{t}-C_{g}}{C_{r}-C_{g}}
\end{gathered}
$$

where $Q$ indicates the discharge of each component, $C$ is the concentration of an observed tracer or an isotopic composition, the subscripts $t, r$, and $g$ indicate total discharge, rainwater, and groundwater, respectively, and $x_{r}$ is the ratio of stream water contributed by rainwater $\left(x_{r}=\frac{Q_{r}}{Q_{t}}\right)$.

The following four assumptions underlie the application of these mass balance equations: (1) There is a significant difference between the concentration of tracers in groundwater and rainwater; (2) the concentrations or isotopic compositions of the tracers for groundwater and rainwater are constant in space and time; (3) for two-component hydrograph separation, the concentrations of each tracer are equivalent in groundwater and vadose water, or else the contribution of vadose water is negligible; and (4) surface storage contributes minimally during the runoff. If these assumptions are valid, then two-component hydrograph separation can be used to determine the amounts of stream water contributed by rainwater and groundwater. Otherwise, hydrograph separation of three or more components should be carried out. For example, if the amount of vadose water in the saturation zone is not negligible and must be taken into account, then hydrograph separation of the three components of runoff, soil water, and groundwater should be used. In two-component systems, soil water can be interpreted as runoff or groundwater, depending on the geological characteristics. When considering the soil water among the factors contributing to the stream water after rainfall or snowmelt, hydrograph separation of the three components (soil water, rain or snowmelt, and groundwater) should be used. Hydrograph separation of the three components is basically expressed in the form of a three-way linear system of equations, which can be interpreted as follows:

$$
Q_{t}=Q_{r}+Q_{g}+Q_{s}
$$




$$
\begin{gathered}
C_{t}=C_{t} \frac{Q_{r}}{Q_{t}}+C_{g} \frac{Q_{g}}{Q_{t}}+C_{s} \frac{Q_{s}}{Q_{t}} \\
I_{t}=I_{t} \frac{Q_{r}}{Q_{t}}+I_{g} \frac{Q_{g}}{Q_{t}}+I_{s} \frac{Q_{s}}{Q_{t}}
\end{gathered}
$$

where $Q$ indicates the discharge of each component, $C$ is the concentration of an observed tracer, $I$ is the isotopic composition of each component, and the subscripts $t, r, g$, and $s$ indicate the total discharge, rainwater, groundwater, and soil water, respectively. Since solutions for more than three components are difficult to obtain, matrix operation has been applied to the Equations (4)-(6) in the present work as follows:

$$
\begin{gathered}
A=\left[\begin{array}{ccc}
1 & 1 & 1 \\
C_{r} & C_{g} & C_{s} \\
I_{r} & I_{g} & I_{s}
\end{array}\right], X=\left[\begin{array}{c}
\frac{Q_{r}}{Q_{t}} \\
\frac{Q_{g}}{Q_{t}} \\
\frac{Q_{s}}{Q_{t}}
\end{array}\right], B=\left[\begin{array}{c}
1 \\
C_{t} \\
I_{t}
\end{array}\right] . \\
A X=B, X=A^{-1} B
\end{gathered}
$$

A system of linear equations is introduced that enables a three-component hydrograph separation using both isotopic and chemical compositions. MATLAB can be used to solve the matrix. These are mathematically underdetermined systems of $n$ equations in $n+1$ unknowns for which there is no unique solution. However, even with $n$ isotope systems and $>n+1$ sources, recently published studies introduce software (IsoSource model) that calculates multiple source proportions using mass balance conservation requirements. The IsoSource model, based on the principle of stable isotope mass conservation, can be used to partition contaminant sources in wastewater [34-36].

According to the second assumption mentioned above, there should be no temporal or spatial variation in the isotopic compositions of groundwater and rainwater (i.e., no isotopic fractionation), which would otherwise lead to deviation. Thus, if the isotopic composition of rain and groundwater changes over time, a systematic error in the fraction of rainwater contributing to the stream will arise. This systematic error can be determined using Gaussian error propagation [37,38]. The isotope composition of groundwater (old water) is known to be relatively constant. However, rain or snowmelt (new water) is subject to much greater isotopic fractionation, so hydrograph separation using the mean isotope value generates errors. The uncertainty of new water generated from isotopic fractionation can be calculated according to the following equation [38]:

$$
\Delta x_{r}=-\frac{x_{r}}{C_{r-} C_{g}} \Delta c_{r}
$$

where $\Delta x_{r}$ is the systematic error when new water (rain or snowmelt) contributes to the stream, and $\Delta c_{r}$ is the error in $c_{r}$. This is the variation in the tracer concentration or the ratio of stable isotopes in the rain (new water). Therefore, according to Equation (9), the error generated when considering the effect of new water on the stream is inversely proportional to the difference of the tracer concentration between new and old water, and directly proportional to the actual contribution of new water $\left(x_{r}\right)$ to the stream water and the tracer concentration of the new water over time $\left(\Delta c_{r}\right)$.

\section{Stable Water Isotopes}

Water evaporates from the ocean and moves into the continents, cools and condenses to form clouds, then falls to the surface as precipitation (rain or snow). In turn, the precipitated water (stream water, groundwater, and runoff) is evaporated again and recycled. As shown in Figure 1, during the transition from ocean to continent, the isotopic composition is changed through the processes of evaporation and rainout within the hydrologic cycle based on the isotope data from Hoefs [39] and Coplen et al. [40]. When water undergoes a change of physical phase, the water molecules containing heavier isotopes $\left(\mathrm{H}^{2} \mathrm{HO}\right.$ and $\left.\mathrm{H}_{2}{ }^{18} \mathrm{O}\right)$ are preferentially concentrated in the more condensed phase (i.e., liquid rather than vapor, and solid rather than liquid), while molecules containing the lighter 
isotope $\left(\mathrm{H}_{2}{ }^{16} \mathrm{O}\right)$ are concentrated in the remaining phase [41]. Consequently, the rainout process causes continual fractionation of heavy isotopes into the precipitation (Rayleigh-like distillation) such that the residual vapor becomes progressively more depleted in heavy isotopes [42]. Hence, subsequent precipitations will be depleted in heavy isotopes compared to previous precipitations originating from the same atmospheric water vapor [43]. Moreover, since the isotope composition of water varies among the components of the water cycle, isotope measurement makes it possible to identify the source of water masses and determine their interrelationships [42]. In particular, because stream water has a complicated relationship between rainfall (new water) and groundwater (old water), isotope composition is a useful tool for determining mixing patterns and relative contribution rates via hydrograph separation [26,38].

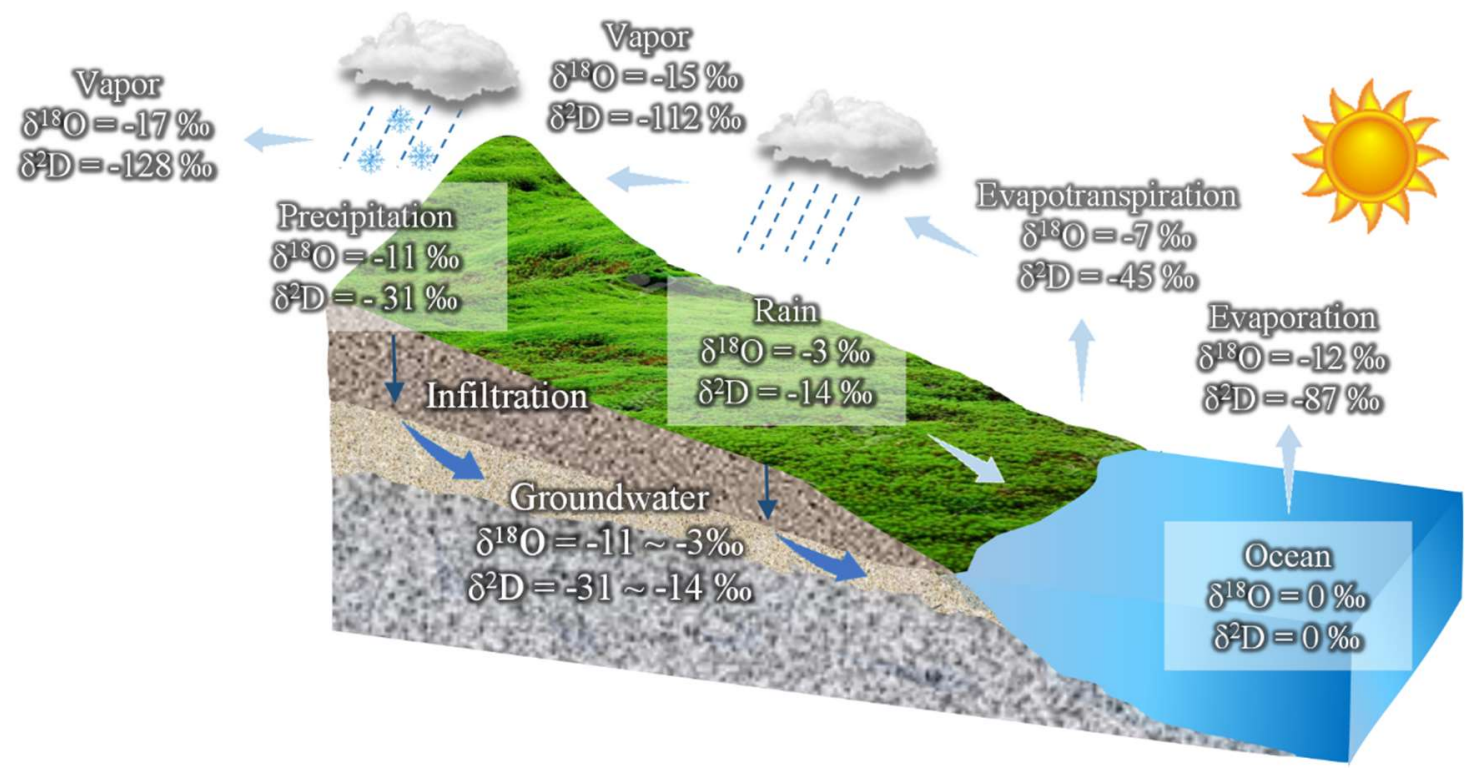

Figure 1. The diagram of isotopic composition change of atmospheric water vapor showing the processes of evaporation and rainout as the air mass proceeds from an ocean to a continent (based on Hoefs [39]; Coplen et al. [40]).

\subsection{Isotopes in Precipitation}

Unlike other tracers, stable water isotopes are added naturally on the scale of the watershed by precipitation (rain or snowmelt events) and, upon entering the watershed, undergo transport according to the natural movement of the body of water through the watershed. Since the stable isotope compositions of the water only change via the above-mentioned mixing and fractionation processes during evaporation and condensation, these environmental isotopes (supplied by meteoric processes) can be used to trace and identify the different air and water masses contributing precipitation to the watershed [43]. Moreover, since precipitation is a major source of water in the hydrological cycle, an understanding of the processes that control the spatial and temporal isotopic composition distributions of precipitation is essential [43].

In general, the fractionation processes of the stable hydrogen and oxygen isotopes are similar; hence, their behavior in the hydrological cycle is also similar [44]. This similarity causes covariance between the stable hydrogen and oxygen isotope concentrations found in most meteoric water, as first observed by Friedman [45]. This covariance can be explained by the following relationship, which was defined by Craig [8]:

$$
\delta^{2} \mathrm{H}=8 \delta^{18} \mathrm{O}+10
$$

This linear relationship, termed the meteoric water line (MWL), provides a convenient reference for understanding and tracing the origins of water [43]. In particular, an MWL with an intercept of 
10 and a slope of 8 has been defined as the global meteoric water line (GMWL). The GMWL may be explained by the condensation of water vapor under conditions close to equilibrium, producing the slope of 8 [46]. The slope is related to the ratio of the fractionation coefficients and to factors relating to whether the water entering the soil, groundwater, and lakes has experienced evaporation [31,47]. Typically, the evaporation of soil or lake water results in a slope of less than 8 (generally between 4 and 7) for the local meteoric water line [46].

In a plot of Equation (10), the y-intercept is termed the deuterium excess (or d-excess). According to Dansgaard [46] this is defined by the deviation of isotopic equilibrium during evaporation from sourced precipitation and is related to the relative humidity parameter of the vapor source for evaporation. Dansgaard [46] recognized four parameters that determine this depletion in isotope values, namely: Altitude, distance from the shore, latitude, and quantity. Since the affected factors differ regionally, the d-excess is useful for identifying moisture source regions [31,48-50]. More recently, Lee et al. [38] reviewed the results of previous studies on how the fractionation of stable water isotopes significantly differs depending upon the region. In the New Hampshire area of the United States, for example, the difference of stable oxygen isotopic value is 2 to 3\% [33] and the stable hydrogen isotopic value is 10 to $12 \%$ o [31], while the isotopic values in Incheon, Korea, are $20 \%$ o for oxygen and approximately $60 \%$ o for hydrogen, and in Jeju Island, Korea, the respective isotopic values of oxygen and hydrogen are 7 to $8 \%$ and 50 to $60 \%$.

The isotopic compositions of precipitation are dependent upon several factors, including those of its vapor source (typically from nearby oceanic regions) along with the processes of precipitation formation and air mass trajectory (i.e., the influence of vapor source and rainout processes along the pathway of the air mass) [43]. Most of these factors are related to isotopic fractionation through diffusion during physical phase changes such as evaporation, sublimation, condensation, and melting [43]. Further details relating to isotopic fractionation will be discussed in the following sections.

\subsection{Isotopic Evolution of Snow}

Snowmelt is the largest contributor to groundwater recharge in Alpine environments [51]. Since snow dynamics are highly variable in space and time, an understanding of the hydrological responses of snowmelt contributing to the watershed is crucial for water-resource management [52]. While the isotopic composition of the snowpack profile generally represents the distinct isotopic composition of individual precipitation events, the signal in the snow layers provided by these individual events is attenuated by isotopic exchange, snowpack metamorphism and surface sublimation [53]. The isotopic composition of snowmelt generated from a snowpack results from two major processes, namely: (1) Sublimation and molecular exchange between vapor and the snowpack, and (2) meltwater infiltration and exchange with snow and meltwater within the snowpack $[31,33,54,55]$.

With respect to the first process, Moser and Stichler [56] indicated that the isotopic fractionation associated with sublimation of snow surfaces behaves similarly to that of evaporating water, although Cooper [53] pointed out an exception when the well-mixed conditions of a water body are not present in the snowpack. In the second process, the meltwater is initially depleted in heavy isotopes relative to the remaining snowpack and then becomes gradually enriched in heavy isotopes as the melting proceeds $[15,33,54]$. This isotopic evolution results from isotopic exchange between liquid water and ice as the liquid water percolates down the snowpack $[15,33,54]$. Consequently, since the isotopic compositions of snowmelt are generally not the same as those of the bulk snow, hydrograph separations based on the isotope composition of the bulk snow will be erroneous [57]. Since snowmelt is a significant component of groundwater and surface runoff in temperate areas, an understanding of the isotopic evolution of a snowpack is crucial to both climatic and hydrological studies.

Studies of artificial and natural snowpack have demonstrated that complex changes in isotopic compositions can be expected to occur between accumulation and melting [58,59]. The isotopic composition of the upper snow layers is significantly altered by sublimation and exchange with atmospheric water vapor. Enrichment in $\delta^{18} \mathrm{O}$ and $\delta^{2} \mathrm{H}$ in the snowpack as a result of evaporation 
is a predictable outcome [60], and theoretical fractionation models developed for evaporation from well-mixed water bodies [61]) are reasonably successful at predicting the effects of simple evaporation once they are modified to account for the less than well-mixed conditions of the natural snowpack. However, isotopic change in the snowpack is more complicated than simple surface evaporation, and is dependent on variable conditions such as soil temperature, soil moisture, relative humidity, air temperature, vegetation cover, and the period of time for which the snowpack is present on the ground. Mast et al. [62] showed that although most of the water in Andrews Creek was new water from snowmelt (based on hydrograph separation using $\delta^{18} \mathrm{O}$ ), much of that water had been transported along subsurface flowpaths prior to reaching the stream, and substantial interaction had occurred with soil or soil-like materials (based on hydrograph separation using dissolved silica). The highest nitrate concentrations in the springs and streams have been found to arise from a combination of the microbial cycle and flushing of nitrates and nitrates directly from rain or snowmelt [12].

\subsection{Stable Water Isotope Measurements}

The stable isotope composition of water is mainly determined by isotope ratio mass spectrometry (IRMS) [63]. This technique measures the relative isotope ratios of molecular compounds by analyzing mass differences [64]. A spectrum of masses is produced by generating a beam of charged molecules (usually by thermal ionization of gaseous samples) then bending the beam in a magnetic field [6]. In general, stable isotope analysis of water using IRMS requires chemical pretreatment [64]. For example, oxygen isotopes require ion-exchange between $\mathrm{H}_{2} \mathrm{O}$ and $\mathrm{CO}_{2}$ via bicarbonate reactions, and hydrogen isotopes require reduction with metals such as uranium, zinc, platinum and chromium [45,65-70]. Consequently, the oxygen isotope composition is analyzed as $\mathrm{CO}_{2}$ and the hydrogen isotope composition is analyzed as $\mathrm{H}_{2}$ [6]. The first dual-inlet mass spectrometer was developed by Alfred Nier in the late 1940s. However, the classical off-line procedures for sample preparation are time consuming and analytical precision depends on the skill of the investigator [6]. These considerations led to the modification of the classic dual inlet technique to create the continuous-flow isotope ratio mass spectrometer in which a trace amount of the gas to be analyzed is delivered in a stream of helium carrier gas [39].

Recently, isotope ratio infrared spectroscopy (IRIS) has been developed to analyze stable water isotopes using laser-based techniques [64]. This technique examines the characteristics of water absorption in the near-infrared wavelength region due to vibration-rotation transitions, which depend upon the ${ }^{18} \mathrm{O}$ and ${ }^{2} \mathrm{H}$ substitution of $\mathrm{H}_{2} \mathrm{O}$ gas molecules [71]. Since these molecular motions are directly related to the proportion of isotopes, the isotope ratio can be measured [72]. The IRIS technique is sub-divided into off-axis integrated cavity output spectroscopy (OA-ICOS) and wavelength-scanned cavity ring-down spectroscopy (WS-CRDS) [64]. Compared to conventional IRMS, the IRIS technique has the advantages of simple preparation and operation, comparative portability for application in the field, and applicability with relatively small amounts of water samples (ppb, ppt) [73-77]. However, the presence of dissolved organic molecules with $\mathrm{O}-\mathrm{H}$ bonds has the disadvantage of degrading analytical performance due to spectral interferences between the dissolved organics and water molecules [78].

\section{Stable Nitrate Isotopes}

\subsection{Pretreatment Method for Nitrate Isotope Analysis}

Dual isotope analysis of nitrates $\left(\delta^{15} \mathrm{~N}\right.$ and $\left.\delta^{18} \mathrm{O}\right)$ can be a powerful tool for identifying nitrate sources and nitrate cycling mechanisms in stream water because the different sources have isotopically distinct $\delta^{15} \mathrm{~N}$ and $\delta^{18} \mathrm{O}$ compositions $[79,80]$. Over the past few decades, several pretreatment methods have been developed to concentrate dissolved nitrates for dual isotope analysis. Until recently, almost all nitrates for both $\delta^{15} \mathrm{~N}$ and $\delta^{18} \mathrm{O}$ analysis were prepared using modifications of the silver nitrate method, in which samples are concentrated on anion exchange resins, eluted, and purified to produce $\mathrm{AgNO}_{3}[80,81]$. The $\mathrm{AgNO}_{3}$ obtained from freeze drying is mixed with a catalyst composed of $\mathrm{CuO} / \mathrm{Cu}$ 
wire/CaO and heated to $850{ }^{\circ} \mathrm{C}$ in a sealed reactor to generate $\mathrm{N}_{2}$ gas for $\delta^{15} \mathrm{~N}$ analysis by IRMS. Meanwhile, $\delta^{18} \mathrm{O}$ is analyzed by mixing $\mathrm{AgNO}_{3}$ with graphite (spectroscopic analysis grade) to obtain $\mathrm{CO}$ gas by pyrolysis or $\mathrm{CO}_{2}$ gas by complete combustion. The combined techniques have been successfully used and published in studies from Alpine, agricultural, and urban environments $[3,82]$. The ion exchange method described above has the advantages of easy transport and storage, direct applicability in the field, and minimal isotope fractionation of nitrate during ion exchange. However, disadvantages of the ion exchange method include the long time and large cost of sample preparation, and interference due to the presence of other anions $\left(\mathrm{Cl}^{-}, \mathrm{SO}_{4}{ }^{2-}\right)$ in the sample. In addition, a relatively large amount of sample is required for precise analysis.

Another nitrate pretreatment method is denitrification by inoculation with a pure culture of denitrifying bacteria that lack the enzyme to reduce nitrate beyond $\mathrm{N}_{2} \mathrm{O}[83,84]$. The gas is then analyzed by IRMS. Microbial denitrification provides a saving in time and cost of sample preparation compared to the silver nitrate method and requires a small amount of sample. Nevertheless, this method involves a long time for culturing the microorganisms and the activity of the microorganisms is affected by toxic substances (antibiotics, heavy metals, pesticides, etc.) in the sample. Moreover, the presence of $\mathrm{NO}_{2}{ }^{-}$may distort the composition of the $\mathrm{N}_{2} \mathrm{O}$ gas. In order to solve these problems, an advanced method of chemically reducing nitrate to $\mathrm{N}_{2} \mathrm{O}$ gas was described by McIlvin and Altabet [85]. In this technique, nitrate $\left(\mathrm{NO}_{3}{ }^{-}\right)$is converted to nitrite $\left(\mathrm{NO}_{2}{ }^{-}\right)$using cadmium reduction and then to nitrous oxide $\left(\mathrm{N}_{2} \mathrm{O}\right)$ using a 1:1 azide and acetic acid solution. The $\mathrm{N}_{2} \mathrm{O}$ gas is analyzed in the same manner as in the microbial denitrification method. This chemical reduction method can significantly reduce the time and cost required for sample preparation and requires a small amount of sample for analysis. In addition, unlike microbial denitrification, it is not affected by toxic substances contained in the sample. However, there is a risk of exposure to dangerous chemicals (cadmium, sodium azide) during the sample pretreatment, and inaccurate data can be obtained due to the $\mathrm{NO}_{2}{ }^{-}$in the sample, as with microbial denitrification.

More recently, besides IRMS, measurements of $\delta^{15} \mathrm{~N}$ and $\delta^{18} \mathrm{O}$ from the headspace $\mathrm{N}_{2} \mathrm{O}$ gas are analyzed in a $\mathrm{N}_{2} \mathrm{O}$ triple isotope analyzer ( $\mathrm{N}_{2} \mathrm{OIA-23e-EP} \mathrm{Model} \mathrm{914-0060;} \mathrm{Los} \mathrm{Gatos} \mathrm{Research,}$ Mountain View, CA, USA) using laser absorption spectroscopy after $\mathrm{N}_{2} \mathrm{O}$ produced by conversion of $\mathrm{NO}_{3}{ }^{-}$by earlier mentioned pretreatment $[86,87]$. The instrument measures $\mathrm{N}_{2} \mathrm{O}$ concentrations $(0.3-20$ ppm), and $\delta^{15} \mathrm{~N}_{\alpha}, \delta^{15} \mathrm{~N}_{\beta}, \delta^{15} \mathrm{~N}_{\text {bulk }}, \delta^{17} \mathrm{O}, \delta^{18} \mathrm{O}$, and $\mathrm{H}_{2} \mathrm{O}$ values in air to precisions of $0.03 \mathrm{ppb}$ for $\mathrm{N}_{2} \mathrm{O}$, less than $\pm 1 \%$ o(SEM) for $\mathrm{N}$ and less than $\pm 2 \%$ o (SEM) for O isotopes over $300 \mathrm{~s}$ of measurement integration [86]. However, the laser spectrometry technique is lower precision and accuracy than IRMS technique (less than $0.2 \%$ o for $\delta^{15} \mathrm{~N}_{-\mathrm{NO}_{3}}{ }^{-}, 0.5 \%$ o for $\delta^{18} \mathrm{O}^{-\mathrm{NO}_{3}}{ }^{-}$) [88].

\subsection{Identification of Contaminant Source Using Nitrate Isotopes}

As previously mentioned, the analyzed nitrate $\delta^{15} \mathrm{~N}$ and $\delta^{18} \mathrm{O}$ isotope ratios provide distinct values for each contaminant source. The value of $\delta^{15} \mathrm{~N}$ in atmospheric $\mathrm{NO}_{3}{ }^{-}$is usually in the range of $-15 \%$ o to $+15 \%$ o $[9,89]$. This large range is due to complex chemical reactions of nitrates or related compounds in the atmosphere, seasons, meteorological conditions, types of anthropogenic inputs, proximity to pollution sources, distance from the ocean, etc. [90]. Synthetic nitrogen fertilizers have $\delta^{15} \mathrm{~N}$ values in the range of $-4 \%$ o to $+4 \%$ [ [79] and the $\delta^{15} \mathrm{~N}$ value of nitrogen in the soil ranges from $-2 \%$ o to $+5 \%$. However, manure and sewage can be more enriched in ${ }^{15} \mathrm{~N}$ due to volatilization of ${ }^{15} \mathrm{~N}$-depleted ammonia, and oxidation of much of the residual waste may result in high $\delta^{15} \mathrm{~N}$ of nitrate [79]. By this process, the $\delta^{15} \mathrm{~N}$ value becomes significant with a range of $+10 \%$ o to $+20 \%$ o [91,92]. Hence, the $\delta^{15} \mathrm{~N}$ is an important indicator of nitrates in the atmosphere, fertilizers, soil, manure and sewage. However, the identification of nitrogen sources and cycles using $\delta^{15} \mathrm{~N}$ values alone is limited because the ranges of values from precipitation, soil, fertilizer, manure, and sewage show substantial overlap (Figure 2). The analysis is therefore used in combination with $\delta^{18} \mathrm{O}$, another indicator for identifying and separating sources of nitrates, in order to reduce the uncertainty of nitrogen isotopes in the identification $[3,18,79,93-96]$. 


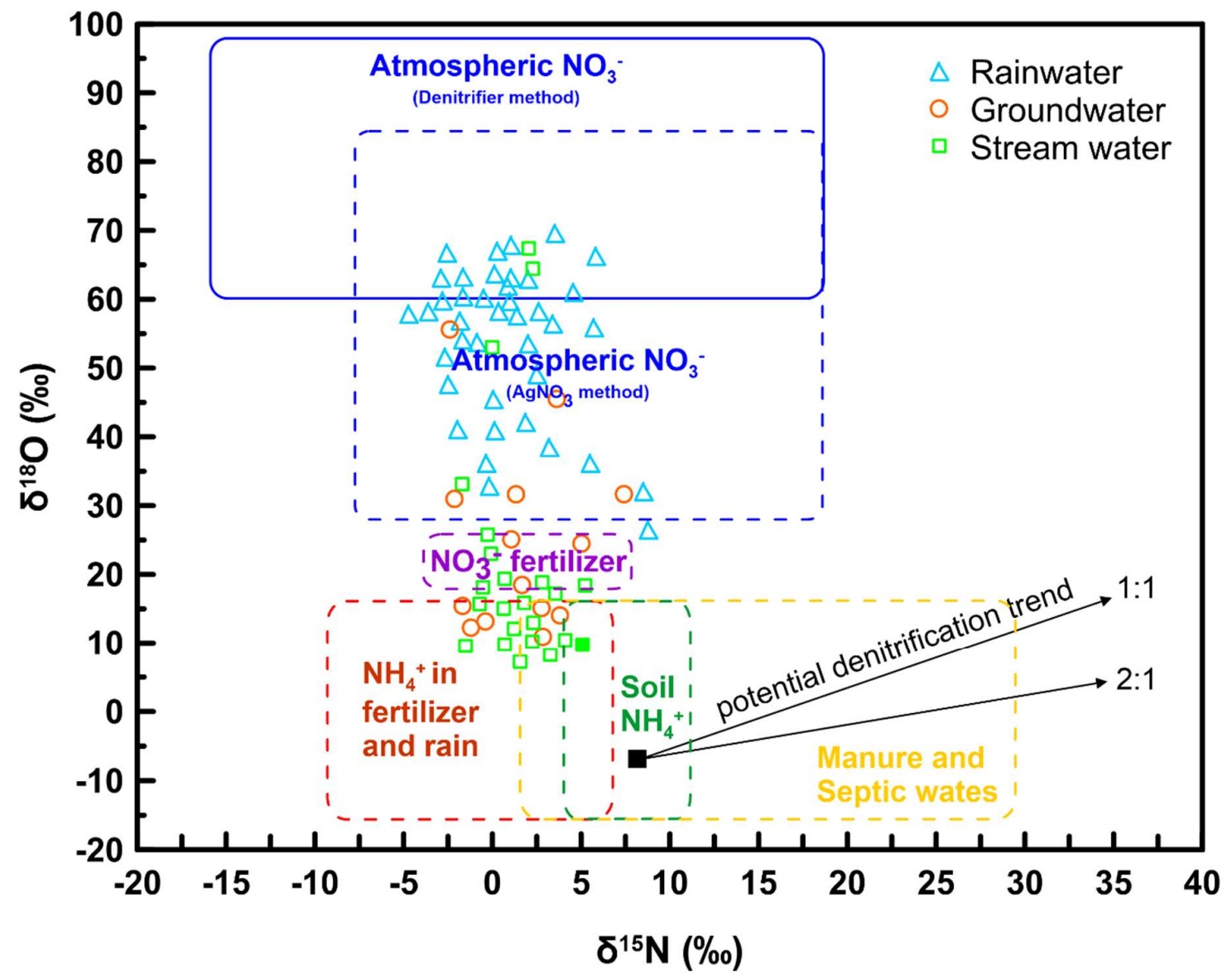

Figure 2. A plot of the $\delta^{15} \mathrm{~N}$ and $\delta^{18} \mathrm{O}$ values of nitrate from various $\mathrm{N}$ sources. The nitrate in stream samples (green squares) was largely derived from groundwater sources. This diagram was modified from Kendall et al. [96] and data from Kendall et al. [79].

The conventional theory asserts that one oxygen atom of newly generated nitrate in soil is derived from dissolved atmospheric oxygen $\left(\mathrm{O}_{2}\right)$ and the other two oxygen atoms are from the surrounding water bodies $[12,18,79,94,97-100]$. If these oxygens are included without any fractionation, and the $\delta^{18} \mathrm{O}$ values of water and atmospheric sources are known, the $\delta^{18} \mathrm{O}$ value of microbial nitrate can be calculated as follows:

$$
\delta^{18} \mathrm{O}_{\mathrm{NO}_{3}}=2 / 3 \delta^{18} \mathrm{O}_{\mathrm{H}_{2} \mathrm{O}}+1 / 3 \delta^{18} \mathrm{O}_{\mathrm{O}_{2}}
$$

While the $\delta^{18} \mathrm{O}$ values of atmospheric-derived nitrates are usually high, between $+20 \%$ and $+70 \%$ o [101], the $\delta^{18} \mathrm{O}$ values of synthetic nitrate fertilizer are $22 \pm 3 \%$; those of soil nitrogen transformed from ammonium via nitrification are between -10 and $+10 \%$; and those of manure and sewage are below 15\% [79]. As such, nitrate shows distinct isotopic composition of nitrogen and oxygen for each contaminant source, which is useful for contaminant source identification. In addition to identifying contaminant source, it can also be used to identify the contribution of contaminant sources using previously mentioned hydrograph separation.

However, the $\delta^{15} \mathrm{~N}$ and $\delta^{18} \mathrm{O}$ values of nitrate are altered by isotopic fractionation due to mineralization, absorption/desorption, nitrification, denitrification, volatilization, assimilation (uptake), and leaching from the soil zone [3]. Common microbial organisms preferentially use the lighter isotopes $\left({ }^{14} \mathrm{~N}\right.$ and $\left.{ }^{16} \mathrm{O}\right)$ over the heavier $\left({ }^{15} \mathrm{~N}\right.$ and $\left.{ }^{18} \mathrm{O}\right)$, so that the microbial products are isotopically depleted and the residual nitrates are enriched in ${ }^{15} \mathrm{~N}$ and ${ }^{18} \mathrm{O}$ [3]. For example, when microbial organisms convert nitrate to nitrogen gases $\mathrm{N}_{2} \mathrm{O}$ (denitrification), the formed nitrogen gases are lighter than the remaining nitrates (low $\delta^{15} \mathrm{~N}$ and $\delta^{18} \mathrm{O}$ ). Therefore, denitrification causes increases in the $\delta^{15} \mathrm{~N}$ 
and $\delta^{18} \mathrm{O}$ values of the residual nitrates, and the enrichment ratios of $\delta^{15} \mathrm{~N}$ and $\delta^{18} \mathrm{O}$ are positively correlated by a factor of between 1.3:1 and 2.1:1 [2,17,79,101-104]. This indicates that, even if isotope fractionation by denitrification occurs, the initial isotope composition can be estimated by knowing the enrichment factor [105].

\subsection{Movements of Nitrate from Surface to Stream}

After reaching the ground, precipitation moves from the surface to the stream, which gradually alters the water isotope composition [42]. These processes typically involve two flow pathways, which are direct and indirect. The direct pathway is the runoff of surface water from rainfall or melting snowpack into the stream water, while the indirect pathway is the vertical movement of dissolved nitrate through the soil profile into the groundwater, after which the groundwater can be flushed out and contribute to the stream water [16,38]. In these processes, the potential sources of nitrates in stream water are atmospheric via rainfall and snowmelt [3], mineralization of soils under snowpacks [106], groundwater [107-109], nitrification [3,12,93], or a combination of these [110]. As mentioned previously, the $\delta^{18} \mathrm{O}$ values of nitrates from atmospheric sources differ significantly from those of groundwater nitrates originating from nitrification in the soil. Thus, if rainfall and surface water run off directly to the stream, the $\delta^{18} \mathrm{O}$ value of nitrate is similar to that of the atmospheric source. However, if precipitation is infiltrated into the soil layer and then recharged to groundwater and released into the stream water, the isotope composition of the stream water is similar to that of the groundwater or soil water. As shown in Figure 2, if the isotopic composition of rainwater and groundwater is determined, the typical isotope values of nitrogen and oxygen can be used to identify the source of stream water and the relative contribution rate.

Many previous studies have shown that groundwater (old water) via indirect pathways is the dominant source for stream water (Table 1). By examining the $\delta^{15} \mathrm{~N}$ and $\delta{ }^{18} \mathrm{O}$ values of nitrate, Kendall et al. [3] concluded that the main source of nitrates in stream water is groundwater, and that a direct contribution of atmospheric-derived nitrate from the snowpack to the stream is a relatively minor source. Ohte et al. [111] studied the nitrate sources of a headwater stream at the Sleepers River Research Watershed in Vermont, USA, during snowmelt using the $\delta{ }^{18} \mathrm{O}$ values of nitrate with precipitation, soil water, and groundwater as the three end members. The results indicated that, as the groundwater was recharged by meltwater and precipitation during snowmelt, the input to the groundwater gradually increased to eventually make it the dominant source of nitrate. As shown in Figure 3, Piatek et al. [109] analyzed $\delta^{15} \mathrm{~N}$ and $\delta^{18} \mathrm{O}$ values of nitrate in the stream and compared them to those of snow and groundwater in the Arbutus Watershed of New York State, NY, USA, to indicate that stream water, atmospherically-derived solutions, and groundwater had overlapping nitrate $\delta^{15} \mathrm{~N}$ values. However, while the $\delta^{18} \mathrm{O}$ values of nitrates displayed similar ranges in stream water and groundwater, these values were significantly lower than those of atmospheric solutions. In addition to these studies, Barnes et al. [112] demonstrated a seasonal variation in the rate of nitrate contribution from atmospheric sources and calculated that, on average, $1-3 \%$ of the summer and $10-18 \%$ of the winter/spring exported stream $\mathrm{NO}_{3}{ }^{-}$is derived from direct atmospheric deposits. Such information is important to the development of efficient and successful abatement strategies that may include ecosystem management, controls on $\mathrm{NO}_{\mathrm{x}}$ emissions and possible correlations of nitrogen exports with climate change [109]. Moreover, $\delta^{15} \mathrm{~N}$ and $\delta^{18} \mathrm{O}$ values of nitrate are useful for identifying the source of nitrate and flowpath process using hydrograph separation because they have distinct isotope values for each source (precipitation, groundwater, soil, etc.). 


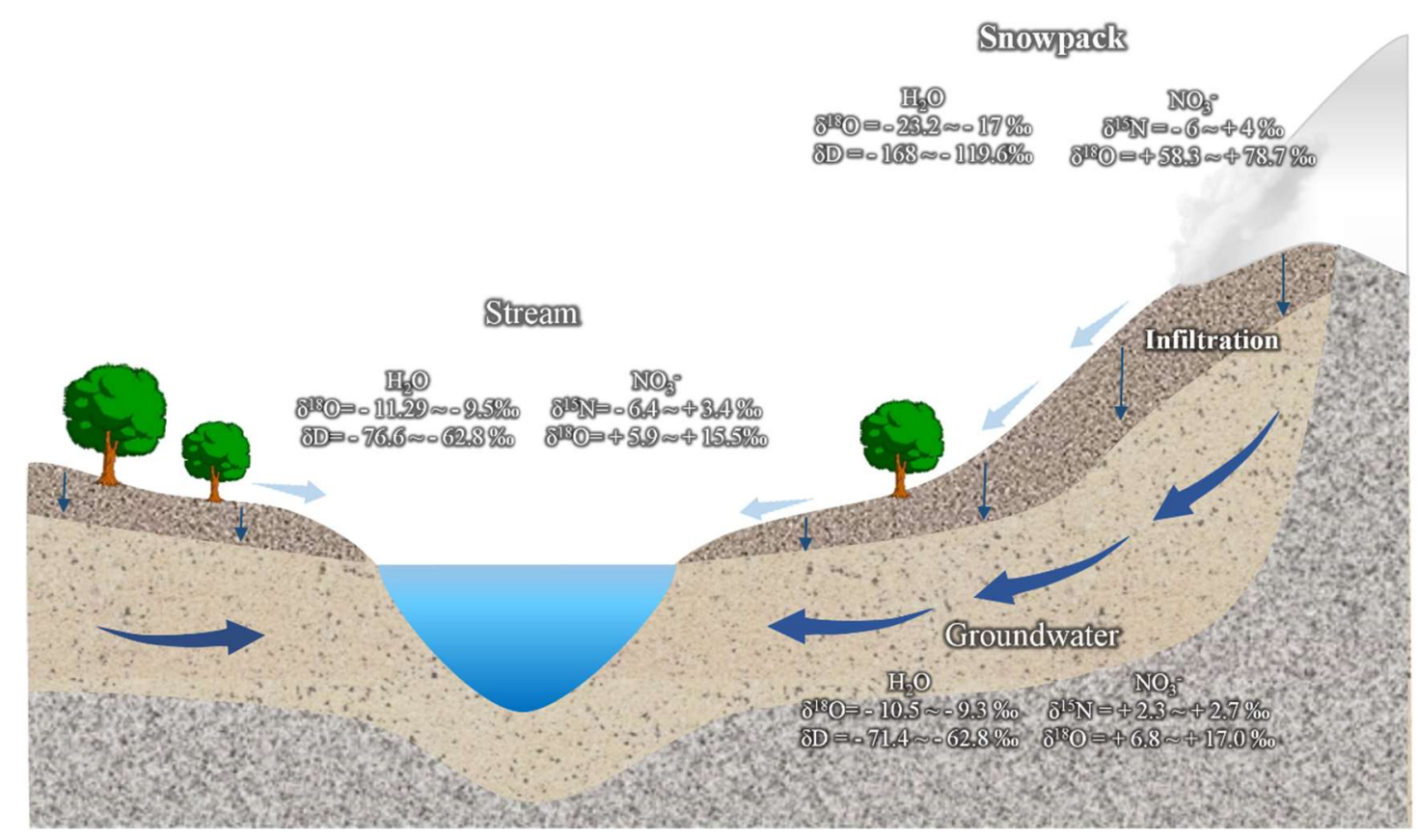

Figure 3. Isotopic compositions of water and nitrate in snowpack, groundwater, stream (data from Kendall [79]; Piatek et al. [109]).

Table 1. Summary of studies that account for more than two different end-members in hydrograph separation using nitrate isotopic tracer.

\begin{tabular}{|c|c|c|c|}
\hline Location & $\begin{array}{c}\text { End-Member } \\
\left(\delta^{15} \mathrm{~N}-\mathrm{NO}_{3}{ }^{-}, \delta^{18} \mathrm{O}-\mathrm{NO}_{3}{ }^{-}\right)\end{array}$ & $\begin{array}{l}\text { Groundwater (Nitrified Sources) } \\
\text { Fraction in Stream Water }\end{array}$ & Reference \\
\hline Bavaria, Germany & $\begin{array}{l}\text { Atmospheric; } \\
\text { Nitrification }\end{array}$ & $84-70 \%$ & [18] \\
\hline $\begin{array}{l}\text { Catskill Mountains, New York State, } \\
\text { USA; } \\
\text { Rocky Mountain National Park, } \\
\text { Colorado, USA; } \\
\text { Danville, Vermont, USA }\end{array}$ & $\begin{array}{l}\text { Snowmelt; } \\
\text { Nitrification }\end{array}$ & Nitrified sources dominant & [3] \\
\hline $\begin{array}{l}\text { Turkey Lakes watershed, Ontario, } \\
\text { Canada }\end{array}$ & $\begin{array}{l}\text { Atmospheric; } \\
\text { Nitrification }\end{array}$ & $70 \%$ & [113] \\
\hline Catskill Mountains, New York, USA & $\begin{array}{l}\text { Precipitation; } \\
\text { Snowmelt; } \\
\text { Soil water }\end{array}$ & Soil water dominant & [93] \\
\hline $\begin{array}{l}\text { Loch Vale watershed, Colorado, } \\
\text { USA }\end{array}$ & Nitrification & $>75 \%$ & [12] \\
\hline $\begin{array}{l}\text { Sleepers River Research Watershed, } \\
\text { Vermont, USA }\end{array}$ & $\begin{array}{l}\text { Precipitation; } \\
\text { Groundwater; } \\
\text { Soil water }\end{array}$ & Groundwater dominant & [111] \\
\hline New Hampshire, USA & Precipitation; Nitrification & $55-100 \%$ & [94] \\
\hline $\begin{array}{l}\text { Arbutus Watershed, New York State, } \\
\text { USA }\end{array}$ & $\begin{array}{l}\text { Wet deposition; } \\
\text { Groundwater }\end{array}$ & $\begin{array}{l}\text { Groundwater dominant during } \\
\text { late winter/early spring }\end{array}$ & [109] \\
\hline Green Mountains, Vermont, USA & $\begin{array}{l}\text { Precipitation; } \\
\text { Soil water }\end{array}$ & $\begin{array}{l}\text { Soil water dominant } \\
\text { during snowmelt periods }\end{array}$ & [114] \\
\hline $\begin{array}{l}\text { Connecticut and Massachusetts, } \\
\text { USA }\end{array}$ & $\begin{array}{l}\text { Microbially produced; } \\
\text { Atmospheric deposition }\end{array}$ & $\begin{array}{c}\text { Summer } 97-99 \% \\
\text { Winter/Spring } 82-90 \%\end{array}$ & [112] \\
\hline Pennsylvania, USA & $\begin{array}{c}\text { Atmospheric sources; } \\
\text { Microbial soil nitrification }\end{array}$ & $67 \%$ & [115] \\
\hline
\end{tabular}


Table 1. Cont.

\begin{tabular}{|c|c|c|c|}
\hline Location & $\begin{array}{c}\text { End-Member } \\
\left(\delta^{15} \mathrm{~N}_{-\mathrm{NO}_{3}}^{-}, \delta^{18} \mathrm{O}-\mathrm{NO}_{3}{ }^{-}\right)\end{array}$ & $\begin{array}{l}\text { Groundwater (Nitrified Sources) } \\
\text { Fraction in Stream Water }\end{array}$ & Reference \\
\hline $\begin{array}{l}\text { Hubbard Brook Experimental } \\
\text { Forest, New Hampshire, USA }\end{array}$ & Precipitation; Nitrification & $\begin{array}{l}66-71 \% \text { during summer rainfall } \\
\text { event }\end{array}$ & [116] \\
\hline $\begin{array}{l}\text { NMR above-ground streams, } \\
\text { Pittsburgh, USA }\end{array}$ & $\begin{array}{c}\text { Atmospheric; } \\
\text { Sewage } \\
\left(\delta^{15} \mathrm{~N}: 0 \% \text { o to }+20 \% \text { o } \delta^{18} \mathrm{O}:-15 \% \text { o }\right. \\
\text { to }+15 \% \text { o })\end{array}$ & $<66 \%$ sewage-derived & [117] \\
\hline $\begin{array}{l}\text { Savannah River, South Carolina, } \\
\text { USA }\end{array}$ & $\begin{array}{c}\text { Throughfall; Trench (soil) water; } \\
\text { Groundwater }\end{array}$ & Groundwater predominant & [118] \\
\hline $\begin{array}{l}\text { Savannah River, South Carolina, } \\
\text { USA }\end{array}$ & $\begin{array}{l}\text { Atmospheric; } \\
\text { Groundwater }\end{array}$ & $\begin{array}{c}\text { Watershed B: 72\% } \\
\text { Watershed R and C: } 90 \%\end{array}$ & [119] \\
\hline
\end{tabular}

\subsection{Implications of the Flowpath of Water and Nitrates}

The stable isotope of nitrate $\left(\delta^{15} \mathrm{~N}\right.$ and $\left.\delta^{18} \mathrm{O}\right)$ can be used to trace the nitrate sources in water bodies because nitrate contaminants usually have distinct isotope compositions [7]. In order to increase the reliability of contaminant tracking, there is a need for a multilateral investigation of precipitation, land-use type and area utilization rates, synthetic fertilizers, animal wastes, the presence of point sources (septic tanks and landfills), and the presence of sewer systems. In addition, hydrogeological data such as groundwater flow rate and direction, aquifer geometry, matrix characteristics, nitrate concentrations, electrical conductivity (EC), redox potential (Eh), and dissolved oxygen (DO) can be used to assess variations in the level of contaminants as well as for tracking contaminant sources.

While isotope analysis is a useful tool for tracking nitrate contaminants, isotope fractionation by nitrification, denitrification, and the presence of multiple contaminants continue to make this difficult. Hence, the use of water stable isotope analysis in combination with the isotopic composition of nitrates may improve the reliability of source identification.

\section{Summary and Perspectives}

Nitrate contamination of stream water has become an environmental problem of global concern [101]. To identify the nitrate source is an effective approach to controlling discharge and emissions of nitrate contamination of stream water. In recent decades, dual nitrate isotope analysis $\left(\delta^{15} \mathrm{~N}\right.$ and $\left.\delta^{18} \mathrm{O}\right)$ has been used as a useful tool for identifying the source and flowpath of nitrate contaminants in water bodies. We have tried to demonstrate in this paper an understanding of the identification water sources and flowpaths process, and the proportion of various sources contributing to stream water via water and nitrate stable isotope technique. However, the application of this method has some limitations due to the multiple nitrogen sources and the influence of isotopic fractionation [101]. In details, nitrates are subjected to multiple physical, chemical, and biological fractionation processes during transport from the original nitrate source to water bodies, and these reactions are influenced by such factors as land-use types, climate, and hydrogeological conditions. Besides, the stable isotope values of nitrate vary according to country or region due to the various regional conditions. To enable the quick and accurate analysis of nitrogen contaminant sources for water bodies, it is therefore suggested that data on the stable isotope values of nitrate from various contaminant sources should be collected in order to establish a global and regional isotope database. For identifying the contaminant sources and tracing the flowpath, it is therefore of great significance to study the influencing factors and transformation processes of nitrates.

More recently, quantification of the relative contributions of nitrate can be improved if other isotope (B, Sr, S, C, Li, U) or chemical tracers [96]. The isotopic signature of boron $\left(\delta^{11} \mathrm{~B}\right)$ in association with the nitrates has been demonstrated [120-125]. Strontium and sulphate isotopes give additional information on the sources of contaminant $[126,127]$. In particular, combined use of boron isotopes with nitrate $\left(\delta^{15} \mathrm{~N}\right.$ and $\left.\delta^{18} \mathrm{O}\right)$ can be a useful tool for nitrate source contributions [120-122,127-129]. Moreover, different nitrate sources can show distinct $\delta^{11} \mathrm{~B}$ values and different processes control the 
isotopic composition of boron and nitrate [120,127]. Moreover, stable isotopes of dissolved nitrates indicate the absence of denitrification, while the coupled use of boron isotopes evidences, even in rural areas, a contribution from septic effluents [130]. Therefore, the combined use of $\delta^{15} \mathrm{~N}_{\mathrm{NO} 3}$, $\delta^{18} \mathrm{O}_{\mathrm{NO}}$, and $\delta^{11} \mathrm{~B}$ is an effective approach to the differentiation of complex $\mathrm{NO}_{3}{ }^{-}$sources, assuming that these compounds co-migrate in many environments $[7,120,121]$. In natural waters, the boron isotopic composition is controlled by the aquifer matrix; the anthropogenic source may be a variable of $\delta^{11} \mathrm{~B}$ [130]. For example, detergents obtained from evaporites, manure, fertilizers, and organic wastes have high concentrations of boron and distinct $\delta^{11} \mathrm{~B}$ values [122,128,130-134].

Likewise, there are many effective multi-isotopic toolboxes for identifying the flowpath and the contaminant source of nitrate. In particular, we discuss hydrograph separation using the oxygen and hydrogen isotopes of water in combination with the nitrogen and oxygen isotopes of nitrate to understand the relative contributions of precipitation and groundwater to stream water. While transformation processes of nitrogen compounds can change the isotopic composition of nitrate due to the various redox processes in the environment, the use of the stable water isotopes of the $\mathrm{H}_{2} \mathrm{O}$ itself can be used to interpret the multiple hydrological and hydrochemical processes for the movement of nitrate contaminants. Therefore, this study will assist in understanding the groundwater flowpaths as well as tracking the sources of nitrate contamination using the stable isotope analysis in combination with nitrate and water. This suggests that source and process information relating to groundwater and nitrates should be made part of the decision-making process in order to better understand and effectively manage the hydrological and nitrogen cycles.

Author Contributions: H.J. was responsible for the implementation of the reference collection, processing and writing of the manuscript. D.-C.K. provided constructive comments and funding. Y.S.K. and S.-W.J. provided constructive comments for this manuscript. J.L. was responsible for the designing and analyzing of the work. All authors have read and agreed to the published version of the manuscript.

Funding: This research was supported by a grant from the National Research Council of Science \& Technology (NST), funded by the Korea government (MSIP) (CAP-17-05-KIGAM). This research was partially funded by the Basic Research Program through the National Foundation of Korea (NRF), which was funded by the Ministry of Education (NRF-2017R1D1A1A09000732).

Acknowledgments: Inputs from two anonymous reviewers improved the quality of this paper.

Conflicts of Interest: The authors declare no conflict of interest.

\section{References}

1. Modica, E.; Buxton, H.T.; Plummer, L.N. Evaluating the source and residence times of groundwater seepage to streams, New Jersey Coastal Plain. Water Resour. Res. 1998, 34, 2797-2810. [CrossRef]

2. Kaushal, S.S.; Groffman, P.M.; Brand, L.E.; Elliott, E.M.; Shields, C.A.; Kendall, C. Tracking Nonpoint Source Nitrogen Pollution in Human-Impacted Watersheds. Environ. Sci. Technol. 2011, 45, 8225-8232. [CrossRef] [PubMed]

3. Kendall, C.; Campbell, D.H.; Burns, D.A.; Shanley, J.B.; Silva, S.R.; Chang, C.C.Y. Tracing sources of nitrate in snowmelt runoff using the oxygen and nitrogen isotopic compositions of nitrate. In Biogeochemistry of Seasonally Snow-Covered Catchments; Tonnessen, K., Williams, M., Tranter, M., Eds.; IAHS Publication: Boulder, CO, USA, 1995; pp. 339-347.

4. Alimi, H.; Ertel, T.; Schug, B. Fingerprinting of hydrocarbon fuel contaminants: Literature review. Environ. Forensics 2003, 4, 25-38. [CrossRef]

5. McGuire, K.; McDonnell, J.J. Stable isotope tracers in watershed hydrology. In Stable Isotopes in Ecology and Environmental Science, 2st ed.; Michener, R., Lajtha, K., Eds.; Wiley/Blackwell: Malden, MA, USA, 2007; pp. 334-540.

6. Clark, I.D.; Fritz, P. Environmental Isotopes in Hydrogeology, 2st ed.; CRC Press: New York, NY, USA, 1997; pp. 13-168.

7. Xue, D.; Botte, J.; De Baets, B.; Accoe, F.; Nestler, A.; Taylor, P.; Van Cleemput, O.; Berglund, M.; Boeckx, P. Present limitations and future prospects of stable isotope methods for nitrate source identification in surface and groundwater. Water Res. 2009, 43, 1159-1170. [CrossRef] 
8. Craig, H. Isotopic Variations in Meteoric Waters. Science 1961, 133, 1702-1703. [CrossRef]

9. Heaton, T.H.E. Isotopic studies of nitrogen pollution in the hydrosphere and atmosphere: A review. Chem. Geol. (Isot. Geosci. Sect.) 1986, 59, 87-102. [CrossRef]

10. Smith, V.H.; Tilman, G.D.; Nekola, J.C. Eutrophication: Impacts of excess nutrient inputs on freshwater, marine, and terrestrial ecosystems. Environ. Pollut. 1999, 100, 179-196. [CrossRef]

11. Liu, C.Q.; Li, S.L.; Lang, Y.C.; Xiao, H.Y. Using $\delta^{15} \mathrm{~N}$ - and $\delta^{18} \mathrm{O}$-Values to Identify Nitrate Sources in Karst Ground Water, Guiyang, Southwest China. Environ. Sci. Technol. 2006, 40, 6928-6933. [CrossRef]

12. Campbell, D.H.; Kendall, C.; Chang, C.C.Y.; Silva, S.R. Pathways for nitrate release from an alpine watershed: Determination using $\mathrm{d}^{15} \mathrm{~N}$ and $\mathrm{d}^{18} \mathrm{O}$. Water Resour. Res. 2002, 38, 1052. [CrossRef]

13. Buttle, J.M.; Sami, K. Recharge processes during snowmelt: An isotopic and hydrometric investigation. Hydrol. Process. 1990, 4, 343-360. [CrossRef]

14. Wels, C.; Cornett, R.J.; Lazerte, B.D. Hydrograph separation: A comparison of geochemical and isotopic tracers. J. Hydrol. 1991, 122, 253-274. [CrossRef]

15. Taylor, S.; Feng, X.; Williams, M.; McNamara, J. How isotopic fractionation of snowmelt affects hydrograph separation. Hydrol. Process. 2002, 16, 3683-3690. [CrossRef]

16. Kim, H.; Cho, S.H.; Lee, D.; Jung, Y.Y.; Kim, Y.H.; Koh, D.C.; Lee, J. Influence of pre-event water on streamflow in a granitic watershed using hydrograph separation. Environ. Earth Sci. 2017, 76, 82. [CrossRef]

17. Böttcher, J.; Strebel, O.; Voerkelius, S.; Schmidt, H.L. Using isotope fractionation of nitrate-nitrogen and nitrate-oxygen for evaluation of microbial denitrification in a sandy aquifer. J. Hydrol. 1990, 114, 413-424. [CrossRef]

18. Durka, W.; Schulze, E.D.; Gebauer, G.; Voerkeliust, S. Effects of forest decline on uptake and leaching of deposited nitrate determined from ${ }^{15} \mathrm{~N}$ and ${ }^{18} \mathrm{O}$ measurements. Nature 1994, 372, 765-767. [CrossRef]

19. Sklash, M.G.; Farvorden, R.N. The role of groundwater in storm runoff. J. Hydrol. 1979, 43, 45-65. [CrossRef]

20. Ladouche, B.; Probst, A.; Viville, D.; Idir, S.; Baqué, D.; Loubet, M.; Probst, J.; Bariac, T. Hydrograph separation using isotopic, chemical and hydrological approaches (Strengbach Catchment, France). J. Hydrol. 2001, 242, 255-274. [CrossRef]

21. Pu, T.; He, Y.; Zhu, G.; Zhang, N.; Du, J.; Wang, C. Characteristics of water stable isotopes and hydrograph separation in Baishui catchment during the wet season in Mt. Yulong region, south western China. Hydrol. Process. 2013, 27, 3641-3648. [CrossRef]

22. Dahlke, H.E.; Lyon, S.W.; Jansson, P.; Karlin, T.; Rosqvist, G. Isotopic investigation of runoff generation in a glacierized catchment in northern Sweden. Hydrol. Process. 2014, 28, 11383-11398. [CrossRef]

23. Li, Z.; Feng, Q.; Jianguo, L.; Yanhui, P.; Tingting, W.; Liu, L.; Guo, X.; Gao, Y.; Jia, B.; Guo, R. Environmental significance and hydrochemical processes at a cold alpine basin in the Qilian Mountains. Environ. Earth Sci. 2015, 73, 4043-4052. [CrossRef]

24. Rahman, K.; Besacier-Monbertrand, A.L.; Castella, E.; Lods-Crozet, B.; Ilg, C.; Beguin, O. Quantification of the daily dynamics of streamflow components in a small alpine watershed in Switzerland using end member mixing analysis. Environ. Earth Sci. 2015, 74, 4927-4937. [CrossRef]

25. Semenov, M.Y.; Zimnik, E.A. A three-component hydrograph separation based on relationship between organic and inorganic component concentrations: A case study in Eastern Siberia, Russia. Environ. Earth Sci. 2015, 73, 611-620. [CrossRef]

26. Lee, J.; Lee, H.J.; Ham, J.Y.; Kim, H. Chemical separation of the discharge generated by artificial rain-on-snow experiments in a snowpack. J. Geol. Soc. Korea 2016, 52, 113-120. [CrossRef]

27. Unnikrishna, P.V.; McDonnell, J.J.; Kendall, C. Isotope variations in a Sierra Nevada snowpack and their relation to meltwater. J. Hydrol. 2002, 260, 38-57. [CrossRef]

28. Laudon, H.; Hemond, H.F.; Krouse, R.; Bishop, K.H. Oxygen 18 fractionation during snowmelt: Implications for spring flood hydrograph separation. Water Resour. Res. 2002, 38, 1258. [CrossRef]

29. Worden, J.; Noone, D.; Bowman, K. Importance of rain evaporation and conti-nental convection in the tropical water cycle. Nature 2007, 445, 528-532. [CrossRef] [PubMed]

30. Yuan, F.; Miyamoto, S. Characteristics of oxygen-18 and deuterium compositionin waters from the Pecos River in America Southwest. Chem. Geol. 2008, 255, 220-230. [CrossRef]

31. Lee, J.; Feng, X.; Faiia, A.M.; Posmentier, E.S.; Kirchner, J.W.; Osterhuber, R.; Taylor, S. Isotopic evolution of a seasonal snowcover and its melt by isotopic exchange between liquid water and ice. Chem. Geol. 2010, 270, 126-134. [CrossRef] 
32. Dincer, T.; Payne, B.R.; Florkowski, T.; Marthinec, J.; Tongiorgi, E. Snowmelt runoff from measurements of tritium and oxygen-18. Water Resour. Res. 1970, 6, 110-124. [CrossRef]

33. Taylor, S.; Feng, X.; Kirchner, J.W.; Osterhuber, R.; Klaue, B.; Renshaw, C.E. Isotopic evolution of a seasonal snowpack and its melt. Water Resour. Res. 2001, 37, 759-769. [CrossRef]

34. Phillips, D.L.; Gregg, J.W. Source partitioning using stable isotopes: Coping with too many sources. Oecologia 2003, 136, 261-269. [CrossRef] [PubMed]

35. Benstead, J.P.; March, J.G.; Fry, B.; Ewel, K.C.; Pringle, C.M. Testing isosource: Stable isotope analysis of a tropical fishery with diverse organic matter sources. Ecology 2006, 87, 326-333. [CrossRef]

36. Meng, Z.; Yang, Y.; Qin, Z.; Huang, L. Evaluating Temporal and Spatial Variation in Nitrogen Sources along the Lower Reach of Fenhe River (Shanxi Province, China) Using Stable Isotope and Hydrochemical Tracers. Water 2018, 10, 231. [CrossRef]

37. Genereux, D. Quantifying uncertainty in tracer-based hydrograph separation. Water Resour. Res. 1998, 34, 915-919. [CrossRef]

38. Lee, J.; Koh, D.C.; Choo, M.K. Influences of Fractionation of Stable Isotopic Composition of Rain and Snowmelt on Isotopic Hydrograph Separation. J. Korean Earth Sci. Soc. 2014, 35, 97-103. [CrossRef]

39. Hoefs, J. Stable Isotope Geochemistry, 4th ed.; Springer: Berlin, Germany, 1997.

40. Coplen, T.B.; Herczeg, A.L.; Barnes, C. Isotope engineering: Using stable isotopes of the water molecule to solve practical problems. In Environmental Tracers in Subsurface Hydrology; Cook, P.G., Herczeg, A.L., Eds.; Kluwer Academic Publishers: Boston, MA, USA, 2000.

41. Ingraham, N.L. Isotopic variation in precipitation. In Isotope Tracers in Catchment Hydrology; Kendall, C., McDonnell, J.J., Eds.; Elsevier: Amsterdam, The Netherlands, 1998; pp. 87-118.

42. Gat, J.R. Oxygen and Hydrogen Isotopes in the Hydrologic Cycle. Annu. Rev. Earth Planet. Sci. 1996, 24, 225-262. [CrossRef]

43. McGuire, K.; McDonnell, J.J. Stable isotope tracers in watershed hydrology. In Stable Isotopes in Ecology and Environmental Science, 2st ed.; Michener, R., Lajtha, K., Eds.; Wiley/Blackwell: Malden, MA, USA, 2007; pp. 334-540.

44. Ingraham, N.L.; Zukosky, K.; Kreamer, D.K. Application of Stable Isotopes to Identify Problems in Large-Scale Water Transfer in Grand Canyon National Park. Environ. Sci. Technol. 2001, 35, 1299-1302. [CrossRef]

45. Friedman, I. Deuterium content of natural waters and other substances. Geochim. Cosmochim. Acta 1953, 4, 89-103. [CrossRef]

46. Dansgaard, W. Stable isotopes in precipitation. Tellus 1964, 16, 436-468. [CrossRef]

47. Blasch, K.W.; Bryson, J.R. Distinguishing Sources of Ground Water Recharge by Using $\delta^{2} \mathrm{H}$ and $\delta^{18} \mathrm{O}$. Groundwater 2007, 45, 294-308. [CrossRef]

48. Merlivat, L.; Jouzel, J. Global climatic interpretation of the deuterium-oxygen 18 relationship for precipitation. J. Geophys. Res. 1979, 84, 5029-5033. [CrossRef]

49. Johnsen, S.J.; Dansgaard, W.; White, J.W.C. The origin of Arctic precipitation under present and glacier conditions. Tellus 1989, 41, 452-468. [CrossRef]

50. Feng, X.; Faiia, A.M.; Posmentier, E.S. Seasonality of isotopes in precipitation: A global perspective. J. Geophys. Res. 2009, 114, D08116. [CrossRef]

51. Koeniger, P.; Hubbart, J.A.; Link, T.; Marshall, J.D. Isotopic variation of snow cover and streamflow in response to changes in canopy structure in a snow-dominated mountain catchment. Hydrol. Process. 2008, 22, 557-566. [CrossRef]

52. Lundquist, J.D.; Cayan, D.R. Seasonal and spatial patterns in diurnal cycles in streamflow in the western united states. J. Hydrometeorol. 2002, 3, 591-603. [CrossRef]

53. Cooper, L.W. Isotopic fractionation in snow cover. In Isotope Tracers in Catchment Hydrology; Kendall, C., McDonnell, J.J., Eds.; Elsevier: Amsterdam, The Netherlands, 1998; pp. 119-136.

54. Lee, J.; Feng, X.; Posmentier, E.S.; Faiia, A.M.; Taylor, S. Stable isotopic exchange rate constant between snow and liquid water. Chem. Geol. 2009, 260, 57-62. [CrossRef]

55. Lee, J. A review on stable isotopic variations of a seasonal snowpack and meltwater. J. Geol. Soc. Korea 2014, 50, 671-679. [CrossRef]

56. Moser, H.; Stichler, W. Use of environmental isotope methods as a reconnaissance tool in groundwater exploration near San Antonio de Pichincha, Ecuador. Water Resour. Res. 1975, 11, 501-505. [CrossRef] 
57. Talyor, S.; Feng, X.; Kirchner, J.W.; Osterhuber, R.; Klaue, B.; Renshaw, C.E. Isotopic evolution of a seasonal snowpack and its melt. Water Resour. Res. 2001, 37, 759-769. [CrossRef]

58. Sommerfield, R.A.; Judy, C.; Friedman, I. Isotopic changes during the formation of depth hoar in experimental snowpacks. In Stable Isotope Geochemistry: A Tribute to Sam Epstein; Taylor, H.P., O'Neil, J.R., Kaplan, I.R., Eds.; The Geochemical Society: San Antonio, TX, USA, 1991; pp. 205-210.

59. Friedman, I.; Benson, C.; Gleason, J. Isotopic changes during snow metamorphism. In Stable Isotope Geochemistry: A Tribute to Sam Epstein; Taylor, H.P., O'Neil, J.R., Kaplan, I.R., Eds.; The Geochemical Society: San Antonio, TX, USA, 1991; pp. 211-221.

60. Rodhe, A. Spring flood: Meltwater or groundwater? Nord. Hydrol. 1981, 12, 21-30. [CrossRef]

61. Craig, H.; Gordon, L.I. Deuterium and oxygen-18 variations in the ocean and the marine atmosphere. In Proceedings of the Conference on Stable Isotopes in Oceanographic Studies and Paleotemperatures. Spoleto, Italy; Tongiorgi, E., Ed.; Consiglio nazionale delle richerche, Laboratorio de geologia nucleare: Pisa, Italy, 1965; pp. 9-130.

62. Mast, M.A.; Kendall, C.; Campbell, D.H.; Clow, D.W.; Back, J. Determination of hydrologic pathways in an alpine-subalpine basin using isotopic and chemical tracers. In Biogeochemistry of Seasonally Snow Covered Catchments; IAHS Publ. 228; Tonnessen, K., Williams, M., Trantner, M., Eds.; IAHS Publication: Boulder, CO, USA, 1995; pp. 263-270.

63. Kendall, C.; Coldwell, E.A. Fundamentals of Isotope Geochemistry. In Isotope Tracers in Catchment Hydrology; Kendall, C., McDonnell, J.J., Eds.; Elsevier: Amsterdam, The Netherlands, 1998; pp. 51-86.

64. Jung, Y.Y.; Koh, D.C.; Ko, K.S.; Lee, J. Applications of Isotope Ratio Infrared Spectroscopy (IRIS) to Analysis of Stable Isotopic Compositions of Liquid Water. Econ. Environ. Geol. 2013, 46, 495-508. [CrossRef]

65. Bigeleisen, J.; Perlman, M.J.; Prosser, H. Conversion of hydrogenic materials for hydrogen to isotopic analysis. Anal. Chem. 1952, 24, 1356-1357. [CrossRef]

66. Epstein, S.; Mayada, T.K. Variations of O-18 content of waters from natural sources. Geochim. Cosmochim. Ac. 1953, 4, 213-224. [CrossRef]

67. Horita, J. Hydrogen isotope analysis of natural waters using an $\mathrm{H}_{2}$-water equilibration method: A special implication to brines. Chem. Geol. 1988, 72, 89-94. [CrossRef]

68. Gehre, M.; Höfling, R.; Kowski, P.; Strauch, G. Sample preparation device for quantitative hydrogen isotope analysis using chromium metal. Anal. Chem. 1996, 68, 4414-4417. [CrossRef]

69. Coplen, T.B.; Wildman, J.D.; Chen, J. Improvements in the gaseous hydrogen-water equilibration technique for hydrogen isotope-ratio analysis. Anal. Chem. 1991, 63, 910-912. [CrossRef]

70. Socki, R.A.; Romanek, C.S.; Gibson, E.K. Online technique for measuring stable oxygen and hydrogen isotopes from microliter quantities of water. Anal. Chem. 1999, 71, 2250-2253. [CrossRef]

71. Kerstel, E. Handbook of Stable Isotope Analytical Techniques, 1st ed.; Elsevier Science: Amsterdam, The Netherlands, 2004; pp. 759-787.

72. Berden, G.; Peeters, R.; Meijer, G. Cavity ringdown spectroscopy: Exerimental schemes and applications. Int. Rev. Phys. Chem. 2000, 19, 565-607. [CrossRef]

73. Wassenaar, L.I.; Hendry, M.J.; Chostner, V.L.; Lis, G.P. High resolution pore water $\delta^{2} \mathrm{H}$ and $\delta^{18} \mathrm{O}$ measurements by $\mathrm{H}_{2} \mathrm{O}$ (liquid)- $\mathrm{H}_{2} \mathrm{O}$ (vapor) equilibration laser spectroscopy. Environ. Sci. Technol. 2008, 42, 9262-9267. [CrossRef]

74. Berman, E.S.F.; Gupta, M.; Gabrielli, C.; Garland, T.; McDonnell, J.J. High-frequency field deployable isotope analyzer for hydrological applications. Water Resour. Res. 2009, 45, W10201. [CrossRef]

75. Gupta, P.; Noone, D.; Galewsky, J.; Sweeney, C.; Vaughn, B.H. Demonstration of high-precision continuous measurements of water vapor isotopologues in laboratory and remote field deployments using wavelength-scanned cavity ring-down spectroscopy (WS-CRDS) technology. Rapid Commun. Mass Spectrom. 2009, 23, 2534-2542. [CrossRef] [PubMed]

76. Hendry, M.J.; Wassenaar, L.I. Inferring heterogeneity in aquitards using high-resolution $\delta \mathrm{D}$ and $\delta^{18} \mathrm{O}$ profiles. Ground Water 2009, 47, 639-645. [CrossRef] [PubMed]

77. Penna, D.; Stenni, B.; Sanda, M.; Wrede, S.; Bogaard, T.A.; Gobbi, A.; Borga, M.; Fischer, B.M.C.; Bonazza, M.; Charova, Z. On the reproducibility and repeatability of laser absorption spectroscopy measurements for $\delta^{2} \mathrm{H}$ and $\delta^{18} \mathrm{O}$ isotopic analysis. Hydrol. Earth Syst. Sci. Discuss. 2010, 14, 1551-1566. [CrossRef] 
78. Brand,W.A.; Geilmann, H.; Crosson, E.R.; Rella, C.W. Cavity ring-down spectroscopy versus hightemperature conversion isotope ratio mass spectrometry: A case study on $\delta^{2} \mathrm{H}$ and $\delta^{18} \mathrm{O}$ of pure water samples and alcohol/water mixture. Rapid Commun. Mass Spectrom. 2009, 23, 1879-1884. [CrossRef]

79. Kendall, C. Tracing nitrogen sources and cycling in catchments. In Isotope Tracers in Catchment Hydrology; Kendall, C., McDonnell, J.J., Eds.; Elsevier: Amsterdam, The Netherlands, 1998; pp. 519-576.

80. Silva, S.; Kendall, C.; Wilkison, D.; Ziegler, A.; Chang, C.C.; Avanzino, R. A new method for collection of nitrate from fresh water and the analysis of nitrogen and oxygen isotope ratios. J. Hydrol. 2000, 228, 22-36. [CrossRef]

81. Chang, C.C.Y.; Langston, J.; Riggs, M.; Campbell, D.H.; Silva, S.R.; Kendall, C. Amethod for nitrate collection for $\delta^{15} \mathrm{~N}$ and $\delta^{18} \mathrm{O}$ analysis from waters with low nitrate concentrations. Can. J. Fish. Aquat. Sci. 1999, 56, 1856-1864. [CrossRef]

82. Wassenaar, L.I. Evaluation of the origin and fate of nitrate in the Abbotsford Aquifer using the isotopes of ${ }^{15} \mathrm{~N}$ and ${ }^{18} \mathrm{O}$ in $\mathrm{NO}_{3}{ }^{-}$. Appl. Geochem. 1995, 10, 391-405. [CrossRef]

83. Sigman, D.M.; Casciotti, K.L.; Andreani, M.; Barford, C.; Galanter, M.; Böhlke, J.K. A Bacterial Method for the Nitrogen Isotopic Analysis of Nitrate in Seawater and Freshwater. Anal. Chem. 2001, 73, 4145-4153. [CrossRef]

84. Casciotti, K.L.; Sigman, D.M.; Galanter Hastings, M.; Böhlke, J.K.; Hilkert, A. Measurement of the Oxygen Isotopic Composition of Nitrate in Seawater and Freshwater Using the Denitrifier Method. Anal. Chem. 2002, 74, 4905-4912. [CrossRef]

85. McIlvin, M.R.; Altabet, M.A. Chemical Conversion of Nitrate and Nitrite to Nitrous Oxide for Nitrogen and Oxygen Isotopic Analysis in Freshwater and Seawater. Anal. Chem. 2005, 77, 5589-5595. [CrossRef]

86. Wassenaar, L.I.; Douence, C.; Altabet, M.; Aggarwal, P. N and O isotope $\left(\delta^{15} \mathrm{~N}_{\alpha}, \delta^{15} \mathrm{~N}_{\beta}, \delta^{18} \mathrm{O}, \delta^{17} \mathrm{O}\right)$ analyses of dissolved $\mathrm{NO}_{3}{ }^{-}$and $\mathrm{NO}_{2}{ }^{-}$by the $\mathrm{Cd}$-azide reduction method and $\mathrm{N}_{2} \mathrm{O}$ laser spectrometry. Rapid Commun. Mass Spectrom 2018, 32, 184-194. [CrossRef] [PubMed]

87. Soto, D.X.; Koehler, G.; Wassenaar, L.I.; Hobson, K.A. Spatio-temporal variation of nitrate sources to Lake Winnipeg using $\mathrm{N}$ and $\mathrm{O}$ isotope $\left(\delta^{15} \mathrm{~N}, \delta^{18} \mathrm{O}\right)$ analyses. Sci. Total Environ. 2019, 647, 486-493. [CrossRef] [PubMed]

88. Liu, X.Y.; Koba, K.; Koyama, L.A.; Hobbie, S.E.; Weiss, M.S.; Inagaki, Y.; Shaver, G.R.; Giblin, A.E.; Hobara, S.; Nadelhoffer, K.J. Nitrate is an important nitrogen source for Arctic tundra plants. Proc. Natl. Acad. Sci. USA 2018, 115, 3398-3403. [CrossRef] [PubMed]

89. Hoering, T. The isotopic composition of the ammonia and the nitrate ion in rain Geochim. Cosmochim. Ac. 1957, 12, 97-102. [CrossRef]

90. Hübner, H.; Fritz, P.; Fontes, J.-C. Handbook of Environmental Isotope Geochemistry: The Terrestrial Environment; Elsevier: Amsterdam, The Netherlands, 1986; Volume 2, pp. 361-425.

91. Kreitler, C.W. Determining the Source of Nitrate in Ground Water by Nitrogen Isotope Studies; Report 83; Bureau of Economics and Geology, University of Texas: Austin, TX, USA, 1975; p. 57.

92. Kreitler, C.W. Nitrogen-isotope ratio studies or soil and ground-water nitrate from alluvial fan aquifers in Texas. J. Hydrol. 1979, 42, 147-170. [CrossRef]

93. Burns, D.A.; Kendall, C. Analysis of $\delta^{15} \mathrm{~N}$ and $\delta^{18} \mathrm{O}$ to differentiate $\mathrm{NO}_{3}{ }^{-}$sources in runoff at two watersheds in the Catskill Mountains of New York. Water Resour. Res. 2002, 38, WR000292. [CrossRef]

94. Pardo, L.H.; Kendall, C.; Pett-Ridge, J.; Chang, C.C.Y. Evaluating the source of streamwater nitrate using $\delta^{15} \mathrm{~N}$ and $\delta^{18} \mathrm{O}$ in nitrate in two watersheds in New Hampshire, USA. Hydrol Process. 2004, 18, 2699-2712. [CrossRef]

95. Savard, M.M.; Somers, G.; Smirnoff, A.; Paradis, D.; van Bochove, E.; Liao, S. Nitrate isotopes unveil distinct seasonal $\mathrm{N}$-sources and the critical role of crop residues in groundwater contamination. J. Hydrol. 2010, 381, 134-141. [CrossRef]

96. Kendall, C.; Elliott, E.M.; Wankel, S.D. Tracing anthropogenic inputs of nitrogen to ecosystems. In Stable Isotopes in Ecology and Environmental Science, 2st ed.; Michener, R., Lajtha, K., Eds.; Wiley/Blackwell: Malden, MA, USA, 2007; pp. 375-449.

97. Andersson, K.K.; Hooper, A.B. $\mathrm{O}_{2}$ and $\mathrm{H}_{2} \mathrm{O}$ and each the source of one $\mathrm{O}$ in $\mathrm{NO}_{2}$ produced from $\mathrm{NH}_{3}$ by Nitrosomonas: ${ }^{15} \mathrm{~N}$ evidence. FEBS Lett. 1983, 164, 236-240. [CrossRef]

98. Kumar, S.; Nicholas, D.J.D.; Williams, E.H. Definitive ${ }^{15} \mathrm{~N} N M R$ evidence that water serves as a source of ' $\mathrm{O}$ ' during nitrite oxidation by Nitrobacter agilis. FEBS Lett. 1983, 152, 71-74. [CrossRef] 
99. Hollocher, T.C. Source of the oxygen atoms of nitrate in the oxidation of nitrite by Nitrobacter agilis: Evidence against a P-O-N anhydride mechanism in oxidative phosphorylation. Arch. Biochem. Biophys. 1984, 233, 721-727. [CrossRef]

100. Voerkelius, S. Isotopendiskriminierungen bei der Nitrifikation und Denitrifikation: Grundlagen und Anwendungen der Herkunfts-Zuordnung von Nitrat und Disickstoffmonoxid. Ph.D. Thesis, Technische University at Munchen, München, Germany, 1990.

101. Zhang, Y.; Shi, P.; Song, J.; Li, Q. Application of Nitrogen and Oxygen Isotopes for Source and Fate Identification of Nitrate Pollution in Surface Water: A Review. Appl. Sci. 2019, 9, 18. [CrossRef]

102. Amberger, A.; Schmidt, H.L. Naturliche Isotopen-gehalte von nitrat als indikatoren fur dessen herkunft. Geochim. Cosmochim. Acta 1987, 51, 2699-2705. [CrossRef]

103. Voerkelius, S.; Schmidt, H.L. Natural oxygen and nitrogen isotope abundance of compounds involved in denitrification: Mitteilungen der Deut. Bodenkundlichen Gesselschaft 1990, 60, 364-366.

104. Burns, D.A.; Boyer, E.W.; Elliott, E.M.; Kendall, C. Sources and Transformations of Nitrate from Streams Draining Varying Land Uses: Evidence from Dual Isotope Analysis. J. Environ. Qual. 2009, 38, 1149-1159. [CrossRef]

105. Jeen, S.W.; Lee, H.; Kim, R.H.; Jeong, H.Y. A Review on Nitrate Source Identification using Isotope Analysis. J. Soil Groundw. Environ. 2017, 22, 1-12.

106. Zak, D.R.; Groffman, P.M.; Pregitzer, K.S.; Christensen, S.; Tiedje, J.M. The vernal dam: Plant-microbe competition for nitrogen in northern hardwood forests. Ecology 1990, 71, 651-656. [CrossRef]

107. Bottomley, D.J.; Craig, D.; Johnston, L.M. Oxygen-18 studies of snowmelt runoff in a small Precambrian shield watershed: Implications for streamwater acidification in acid-sensitive terrain. J. Hydrol. 1986, 88, 21-234. [CrossRef]

108. McHale, M.R.; McDonnell, J.J.; Mitchell, M.J.; Cirmo, C.P. A field based study of soil- and groundwater nitrate release in an Adirondack forested watershed. Water Resour. Res. 2002, 38, 1029-1038. [CrossRef]

109. Piatek, K.B.; Mitchell, M.; Silva, S.R.; Kendall, C. Sources of Nitrate in Snowmelt Discharge: Evidence from Water Chemistry and Stable Isotopes of Nitrate. Water Air Soil Pollut. 2005, 165, 13-35. [CrossRef]

110. Schleppi, P.; Hagedorn, F.; Providoli, I. Nitrate leaching from a mountain forest ecosystem with Gleysols subjected to experimentally increased N. deposition. Water Air Soil Pollut. 2004, 4, 453-467. [CrossRef]

111. Ohte, N.; Sebestyen, S.D.; Shanley, J.B.; Doctor, D.H.; Kendall, C.; Wankel, S.D.; Boyer, E.W. Tracing sources of nitrate in snowmelt runoff using a high-resolution isotopic technique. Geophys. Res. 2004, 31, L21506. [CrossRef]

112. Barnes, R.T.; Raymond, P.A.; Casciotti, K.L. Dual isotope analyses indicate efficient processing of atmospheric nitrate by forested watersheds in the northeastern U.S. Biogeochemistry 2008, 90, 15-27. [CrossRef]

113. Spoelstra, J.; Schiff, S.L.; Elgood, R.J.; Semkin, R.G.; Jeffries, D.S. Tracing the sources of exported nitrate in the Turkey Lakes Watershed using ${ }^{15} \mathrm{~N} /{ }^{14} \mathrm{~N}$ and ${ }^{18} \mathrm{O} /{ }^{16} \mathrm{O}$ isotopic ratios. Ecosystems 2001, 4, 536-544. [CrossRef]

114. Hales, H.C.; Ross, D.S.; Lini, A. Isotopic signature of nitrate in two contrasting watersheds of Brush Brook, Vermont, USA. Biogeochemistry 2007, 84, 51-66. [CrossRef]

115. Buda, A.R.; DeWalle, D.R. Dynamics of stream nitrate sources and flow pathways during stormflows on urban, forest and agricultural watersheds in central Pennsylvania, USA. Hydrol. Process. 2009, 23, 3305-3392. [CrossRef]

116. Wexler, S.K.; Goodalea, C.L.; McGuire, K.J.; Bailey, S.W.; Groffman, P.M. Isotopic signals of summer denitrification in a northern hardwood forested catchment. Proc. Natl. Acad. Sci. USA 2014, 111, 16413-16418. [CrossRef]

117. Divers, M.A.; Elliott, E.M.; Bain, D.J. Quantification of Nitrate Sources to an Urban Stream Using Dual Nitrate Isotopes. Environ. Sci. Technol. 2014, 48, 10580-10587. [CrossRef]

118. Klaus, J.; McDonnell, J.J.; Jackson, C.R.; Griffiths, N.A. Where does streamwater come from in low-relief forested watersheds? A dual-isotope approach. Hydrol. Earth Syst. Sci. 2015, 19, 125-135. [CrossRef]

119. Griffiths, N.A.; Jackson, C.R.; McDonnell, J.J.; Klaus, J.; Du, E.; Bitew, M.M. Dual nitrate isotopes clarify the role of biological processing and hydrologic flowpaths on nitrogen cycling in subtropical low-gradient watersheds. J. Geophys. Res. Biogeosci. 2016, 121, 422-437. [CrossRef]

120. Seiler, R.L. Combined use of ${ }^{15} \mathrm{~N}$ and ${ }^{18} \mathrm{O}$ of nitrate and ${ }^{11} \mathrm{~B}$ to evaluate nitrate contamination in groundwater. Appl. Geochem. 2005, 20, 1626-1636. [CrossRef] 
121. Widory, D.; Kloppmann, W.; Chery, L.; Bonnin, J.; Rochdi, H.; Guinamant, J. Nitrate in groundwater: An isotopic multi-tracer approach. J. Contam. Hydrol. 2004, 72, 165-188. [CrossRef] [PubMed]

122. Widory, D.; Petelet-Giraud, E.; Negrel, P.; Ladouche, B. Tracking the sources of nitrates in groundwater using coupled nitrogen and boron isotopes: A synthesis. Environ. Sci. Technol. 2005, 39, 539-548. [CrossRef] [PubMed]

123. Saccon, P.; Leis, A.; Marca, A.; Kaiser, J.; Campisi, L.; Bottcher, M.E.; Savarino, J.; Escher, P.; Eisenhauer, A.; Erbland, J. Multi-isotope approach for the identification and characterization of nitrate pollution sources in the Marano lagoon (Italy) and parts of its catchment area. Appl. Geochem. 2013, 34, 75-89. [CrossRef]

124. Puig, R.; Soler, A.; Widory, D.; Mas-Pla, J.; Domènech, C.; Otero, N. Characterizing sources and natural attenuation of nitrate contamination in the Baix Ter aquifer (NE Spain, using a multi-isotope approach). Sci. Total Environ. 2017, 580, 518-532. [CrossRef]

125. Martinelli, G.; Dadomo, A.; De Luca, D.A.; Mazzola, M.; Lasagna, M.; Pennisi, M.; Pilla, G.; Sacchi, E.; Saccon, P. Nitrate sources, accumulation and reduction in groundwater from Northern Italy: Insights provided by a nitrate and boron isotopic database. Appl. Geochem. 2018, 91, 23-35. [CrossRef]

126. Vitòria, L.; Otero, N.; Soler, A.; Canals, A. Fertilizer characterization: Isotopic data (N, S, O, C, and Sr). Environ. Sci. Technol. 2004, 38, 3254-3262.

127. Nestler, A.; Berglund, M.; Accoe, F.; Duta, S.; Xue, D.; Boeckx, P.; Taylor, P. Isotopes for improved management of nitrate pollution in aqueous resources: Review of surface water field studies. Environ. Sci. Pollut. Res. 2011, 18, 519-533. [CrossRef]

128. Komor, S.C. Boron content and isotopic composition of hog manure, selected fertilizer, and water in Minnesota. J. Environ. Qual. 1997, 26, 1212-1222. [CrossRef]

129. Leenhouts, J.M.; Bassett, R.L.; Maddock Iii, T. Utilization of intrinsic boron isotopes as Co-migrating tracers for identifying potential nitrate contamination sources. Ground Water 1998, 36, 240-250. [CrossRef]

130. Sacchi, E.; Acutis, M.; Bartoli, M.; Brenna, S.; Delconte, C.A.; Laini, A.; Pennisi, M. Origin and fate of nitrates in groundwater from the central Po plain: Insights from isotopic investigations. Appl. Geochem. 2013, 34, 164-180. [CrossRef]

131. Vengosh, A.; Heumann, K.G.; Juraske, S.; Kasher, R. Boron isotope application for tracing sources of contamination in groundwater. Environ. Sci. Technol. 1994, 28, 1968-1974. [CrossRef]

132. Eisenhut, S.; Heumann, K.G.; Vengosh, A. Determination of boron isotopic variations in aquatic systems with negative thermal ionization mass spectrometry as a tracer for anthropogenic influences. Fresenius' J. Anal. Chem. 1996, 354, 903-909. [CrossRef] [PubMed]

133. Barth, S. Application of boron isotopes for tracing sources of anthropogenic contamination in groundwater. Water Res. 1998, 32, 685-690. [CrossRef]

134. Barth, S.R. Boron isotopic compositions of near-surface fluids: A tracer for identification of natural and anthropogenic contaminant sources. Water Air Soil Pollut. 2000, 124, 49-60. [CrossRef] 